\title{
Review of How Theatre Means
}

How Theatre Means. By Ric KNOWLES. Basingstoke: Palgrave Macmillan, 2014. 234pp. ISBN 9780-2302-3235-8 (hb), 978-0-2302-3236-5 (pb).

In 2014, Palgrave Macmillan published Ric Knowles' book on theatre semiotics, advertising in this way 'clear and accessible, this book brings a key analytical methodology to life for students, practitioners and scholars' (as printed on the book cover). ${ }^{1}$ Knowles does indeed provide a key analytical methodology and succeeds in making it clear and accessible. He also succeeds in using semiotic tools in analysing contemporary intercultural performance and in laying out its semantic energies. In this book review, I would like to not only commend the book but also point out a couple of methodological and theoretical problems the book brings - as well as sharing my experience in teaching this book as a fundamental text. ${ }^{2}$

Making meaning in the theatre is key. However, as Knowles says in the opening passage:

To mean is not the only thing that theatre does - it also entertains, and moves - but

1 This article is published as part of the research grant project Czech Structuralist Thought on Theatre: context and potency, held by the Faculty of Arts, Masaryk University, Brno, 2011-2015; funded by the Czech Grant Agency, grant no. GA409/11/1082.

2 The module called Really Serious Theory (09195) was taught in Semester 1 of 2014/2015 in the School of Drama, Music and Screen at the University of Hull. The students participating and contributing to the experience I share here were: Erin Billington, Eleanor Bond, Caitlin Derham, Emily Fozard, Louise Gilpin, Siana-Mae Heppell-Secker, Joshua Overton, Rory Powrie, Oliver Sturges, and Harriet Wilkinson. it is one of the most important things. This is so because one of theatre's primary functions is to serve as a live forum for the negotiation of values within and between cultures. (2)

This is certainly true, although one could add many more things that theatre does as I will suggest below. Knowles hastens to add, in order to clarify the remit of his book:

It [theatre] is a place where communication happens, and for students of the theatre from the elementary to the most advanced level, to understand how this communication and these negotiations occur - how meanings are encoded and decoded - is essential. (2)

Is it really so? Is meaning expected to dominate in the understanding of theatre (and in theatre theory) - as if all activities, including ruminations, productive procrastination, bemusement, wondering, the blessed state of 'not knowing yet' as well as enjoying the presence of others - are to turn into the productive purposefulness of finding meaning? Aren't we in this way turning theatre into a didactic institution of sorts that a patronising Enlightenment intellectual would subscribe to and that the anti-theatrical pamphleteers of former times would be ready to tolerate? In other 
words, do we need this 'productivity' justification so that we may study theatre? Do we have to bow down to the demagogic logic of 'for the public good' and 'do the right thing'? Isn't the art of cultivating shared existence and making space for a public social life enough? I would claim that in the time of modern public and social media, the theatre and performing arts in general are becoming the only art of cultivating time shared with other people. A concert, a dance performance, a theatre play cannot be switched off by the click of a mouse, or paused by a remote when we are distracted by other vagaries of the self. The live performing arts are luckily the only forms that are not clickable and subject to the individual will; in them, individuals are subduing themselves to the people around them - the others with whom we share the world. I believe that it is this undeniable right that remains unique to the art that has almost fallen victim to film, television and the internet.

This is not so say that Knowles is unaware of this; the final sentence of the book - an envoi of sorts - opens further horizons:

Finally, any good performance analysis in the $21^{\text {st }}$ century must pay primary attention, not to building huge and universal edifices of meaning, but to the shifting grounds of difference. (207)

(Let us bypass what the last word refers to.) Knowles acknowledges the shifting grounds in theatre and the limitations of a purely meaning-related performance analysis. The polemical point I would like to raise here is that since the semiotic age (of the 1970s and 1980s) our social reality has developed, and so has theatre. I believe that theatre theory should therefore focus on what is unique to its discipline and reflect the true 'battlefield' of current theatre practice - its structural dominant, to use Jan Mukařovskýs term. (Knowles does refer to Mukařovský - citing one of his essays in Italian, although the 1931 Czech original was published in English in 1982, too; MUKAŘOVSKÝ 1982.)

In Part II of How Theatre Means, Knowles focuses on a theatre project he was involved in in Toronto: '[a]s I write this introduction [I am making] a new play, Chocolate Woman Dreams the Milky Way' (1), and he 'see[s the] performance through a semiotic lens for the analysis of specific scripts, processes, and plays in production' (111). To that end, he draws two lists kinds of aides-mémoires - first, 'a number of assumptions drawn from the history of semiotic theory' (112), and second, 'some concepts' outlined previously, 'shifting their focus from theory to "practice" and in particular the practices of making theatre' (113). These are helpful checklists for a novice theoretician - but there is a problem: all of these assumptions and concepts bring along a cultural and philosophical baggage that I would argue is counterproductive and misleading. Let me give an example of the first item on the first list:

1. Everything on stage, and everything involved in 'the entire theatre experience', is a sign. (112)

This assumption has been previously posited (p. 9) and linked back to the Czech 
Structuralist Jiří Veltruskýs 1940 essay 'Man and Object in the Theater', originally a lecture delivered at the Prague Linguistic Circle, in which Veltruský claims that 'All that is on the stage is a sign' (V̌̌echno, co je na scénè, je znakem, VELTRUSKÝ 1940: 155; GARVIN 1964: 84). Knowles, just like many others, has taken this as proven fact.

The problem is that this notorious adage is of course not true although for three quarters of a century it has served as a handy rule-of-thumb that removes a big theoretical burden and generally makes the theorist's life much easier. In his posthumous An Approach to the Semiotics of Theatre, Veltruský modifies his earlier rash claim and cites Jan Mukařovský ('On the Current State of the Theory of Theatre', 1941) and František Deák ('Structuralism in Theatre: The Prague School Contribution', 1976).

Acting is a factor of unification because the actor is personally present in all the signs he produces. Since acting is therefore perceived not only through the senses but also through direct intuition, or empathy, it stands at the centre of the whole theatrical performance and determines the meaning of everything to be seen on the stage and everything that happens there. (VELTRUSKÝ 2012: 171-2)

Not everything on the stage is a sign a spotlight is not, neither is the language (English, Arabic, Czech) in which the performance is played, nor is the stray cat in a site-specific show - unless it is actively brought into the action. It is only through the actor's semantic gesture (HONZL 1940) that objects, people, words - phe- nomena tout court - acquire meaning that contributes to the play; only then they may become signs (see also DRÁBEK 2014). Besides, a chair on stage that is used as a chair is actually not a sign of a chair but a chair - shown in an act of ostension (OSOLSOBĚ 2010 [1986]). Even if the chair was used as a horse, it doesn't need to be understood semiotically; what is ostended is the quality and act of sitting. So theatre may be perceived both semiotically (as a sign system), or non-semiotically (as acts of ostension).

Knowles' lists are ready-made rules-ofthumb in laying out the 'arsenal' that theatre has at hand. Naturally, going through the lists and applying the assumptions and concepts doesn't make good theatre yet. Although Knowles admits (in the last paragraph of the book) that 'there is no uniform checklist that applies to all productions' (206), I would even be apprehensive that this approach may result in a mechanistic creativity - not uncommon in commercial culture. But again, doesn't this actually push theatre out of its currently unique selling point towards expressive techniques it shares with its next of kin (film, TV...)? Wouldn't it be more in keeping with Knowles' own focus on the process (rather than product) of the making of a theatre production to abandon listing techniques and tools - that eventually become part of theatre production and concentrate instead on the process of creating new performance realities that in turn dominate the entire production - that is, on the transformative power of performance, as Erika Fischer-Lichte has called it recently (FISCHER-LICHTE 2008)? That 
would be a more appropriate way of grappling theoretically with what Knowles calls:

pragmatism that lives with postmodern uncertainties, multicultural complexities, and the sheer messiness of theatrical production, where on-set signs can reveal their materiality by crashing down like badly built flats, and the copulation of signs can issue in real-life pregnancies. (7)

It is almost as if Knowles acknowledged that 'a purely Structuralist or narrowly scientific approach to a semiotics of performance' comes short of handling present-day theatre reality. That is certainly an unsurprising inference - but the controversy lies deep in the heart of this book. Unnecessarily, since the development of semiotics did not end in the 1990s and has reflected developments in other fields too. The omission of current European theatre theory such as Fischer-Lichte herself or the recent reassessments of early Structuralism - are surprising gaps in this book. As an indirect consequence, the modern realities of theatre are approached with theoretical tools that are somewhat incapacitated - for instance, when Knowles reflects on the limits of representation:

But all representations are misrepresentations; if they weren't they would be the thing itself, and would be unnecessary. Representations are useful only insofar as they do substitute for the 'real thing'; that is, they are useful only insofar as they are misrepresentations. That is the work they do. (3)
To be sure, such syllogisms are not very helpful in introducing the student to the benefits of semiotics - especially on page 3 - as my own teaching experience testifies. Accompanied by such as mindboggling disputations as:

Accepting or assenting to such misrecognitions always risks operating in the realms of cliché and stereotype, risks participating in a representational economy that values some aspects of what is represented over others, and risks universalizing certain traits. Indeed, we risk policing the 'appropriate', 'normal', or valued characteristics of elements of the world and of humanity each time we say of a representation, 'yes, I recognize that.' (4)

- these passages do raise serious doubts about the usefulness of such terms as representation, recognition or even sign. What has come up in discussions of these and other heavily conceptual passages of the book is the notion of metaphor and the importance of metaphorical perception in performance. The metaphor in its own nature 'goes beyond' the literal and disentangles the mind from the shackles of representation, recognition and even of the mechanical usage of semiotics.

With the knowledge of recent theories of metaphor - be it Zoltán Kövecses's studies (KÖVECSES 1993), through Ted Cohen's philosophical as well as theatrical essays (as in Chapter 5 of COHEN 2008), to James Geary's more popular, yet rigorous overview of metaphor usage (GEARY 2011) - theatre semiotics has assumed 
a wholly new dimension that recognises and incorporates the phenomenological (and occasionally psychological) roots of Structuralism and semiotics, and combines further epistemological disciplines in a more efficient theoretical methodology of understanding what happens in theatre - not only on stage but also (very importantly) in the human collective that has gathered to experience the play as well as in the human mind and its (inter) subjective interaction - the acts of seeing, hearing, feeling; being bemused, lost, not knowing yet, guessing, mistaking - and maybe, eventually, coming to a more consistent 'product' of the experience. But to be sure, the product is not the end. Besides, using de Saussure's, Peirce's and other linguistic semiotics for the analysis of theatre is to use them metaphorically. Theatre - unlike language - operates in pre- or non-conceptual realities - sounds, tones, rhythms, colours, space, emotions... To treat them semiotically in a literal way would rob the theatre experience of its power to overwhelm and baffle our conceptual world.

Ric Knowles' How Theatre Means is a concise probe into theatre semiotics and provides an accessible guide to the various channels of communication that take flow in theatre. The book is, at the same time, an invitation to move beyond the elements and approaches that it outlines, to attempt to understand what makes theatre unique and more than a sum of its meanings.

\section{Bibliography}

COHEN, Ted. 2008. Thinking of Others: On the Talent for Metaphor. Princeton: Princeton University Press, 2008.

DRÁBEK, Pavel. 2014. Functional Reformulations: Prague School and Intralingual Translation. In Barbora Př́hodová and Tomáš Kačer (eds.). Prague Semiotic Stage Revisited II. A special issue of Theatralia 17: 2 (Autumn 2014): 81-95.

FISCHER-LICHTE, Erika. 2008. The Transformative Power of Performance: A New Aesthetics. Transl. by Saskya Iris Jain. Abingdon: Routledge, 2008. German original: Ästhetik des Performativen (2004).

GEARY, James. 2011. I Is an Other: The Secret Life of Metaphor and How It Shapes the Way We See the World. New York: HarperCollins, 2011.

HONZL, Jindřich. 1940. Pohyb divadelního znaku [Dynamics of the Theatrical Sign]. Slovo a slovesnost [The Word and Verbal Art] 6 (1940): 177-88. An English translation by Irwin R. Titunik was published as 'Dynamics of the Sign in the Theater' in Ladislav Matějka and Irwin R. Titunik (eds). Semiotics of Art: Prague School Contributions. Cambridge (Mass.): MIT Press, 1976: 74-93.

KÖVESCES, Zoltán. 1993. Metaphor: A Practical Introduction. Oxford: Oxford University Press, 1993.

MUKǍ̌OVSKÝ, Jan. 1982. An Attempt at a Structural Analysis of an Actor's Figure (Chaplin in City Lights). In Peter Steiner (ed.). The Prague School. Selected Writings 1929-1946. Austin, 1982: 171-7. 
OSOLSOBĚ, Ivo. 2010. Ostension. In Thomas A. Sebeok and Marcel Danesi (eds.). Encyclopedic Dictionary of Semiotics. $3^{\text {rd }}$ revised and updated ed. Berlin, New York: Mouton de Gruyter, 2010.

VELTRUSKÝ, Jiří. 1940. Člověk a předmět na divadle [Man and Object in the Theatre]. Slovo a slovesnost 6 (1940): 153-9. An English translation in Paul Garvin (ed.). 1964.
A Prague School Reader on Esthetics, Literary Structure, and Style. Washington: Georgetown University Press, 1964: 83-91.

VELTRUSKÝ, Jiří. 2012. An Approach to the Semiotics of Theatre. Reconstructed, translated in English and prefaced by Jarmila F. Veltrusky. Ed. Tomáš Hoskovec, David Drozd. Brno: Masaryk University, 2012.

DOI: $10.5817 /$ TY2015-2-21 